\title{
Mental health services in the former Soviet Union: decline and despondency
}

\author{
David Skuse
}

Behavioural and Brain Sciences Unit, Institute of Child Health, London WC1N 1EH, UK, email dskuse@ich.ucl.ac.uk

Since ince the collapse of the Soviet Union in 1990/91, there have been major changes in the political landscape of the former Soviet states. These have been mirrored in less publicised reforms of the way in which healthcare has been delivered. Here we focus on the way in which psychiatric services have developed in Ukraine and Moldova.

Igor Martsenkovsky and colleagues discuss the state of Ukrainian health services since the final years of the USSR, when, they report, there was increasing corruption and a deterioration in funding. Investment in health services since then has, they argue, been inadequate. Certainly, the current government is not functioning as well as it should, in part because of tensions between the pro-Western Yulia Tymoshenko, the prime minister, and Viktor Yushchenko, the president. There is high inflation, and Ukraine is dependent upon Russia for oil and gas, which has made its rulers nervous of becoming too closely allied to the West. Readers will recall that it was in Ukraine, in 1986, that a reactor at the Chernobyl nuclear power plant exploded, with devastating health consequences for the people of that country.

The authors report a recent move to reform healthcare in Ukraine, and to build an extended primary care network. This is going to mean, according to the report published here, that primary healthcare practitioners will be given greater responsibility to assess and treat mental illness, although it is not clear who is going to train them to do so. There may be, as a consequence, a reining back of the extensive secondary care provisions which had been built up within the Soviet system.
A similar theme, but with a different emphasis, is explored in the article by Andriy Samokhvalov and colleagues on the subject of alcohol misuse in Ukraine. Consumption of alcohol is much higher than in many other European countries, and among the top $5 \%$ of all countries globally. Heavy drinking starts young, in early adolescence, and virtually nobody is teetotal. The historical background to this situation, over the past 40 years, is fascinating. There appears to have been a national loss of confidence, demoralisation, and sense of helplessness that continue to this day. We learn that one of the most effective campaigns to counter alcohol misuse was introduced by Mikhail Gorbachev, in the mid-1980s, but after 10 years its unpopularity had led to its abandonment.

The third article concerns mental healthcare reform in Moldova, which became independent in 1991 upon dissolution of the Soviet Union. Moldova is a small, poor country, where the healthcare system has deteriorated since 1991 because of social and economic problems. It is tucked under the southern border of Ukraine, and has many of the same aspirations. It also neighbours Romania, and would like to be part of the European Union. In Moldova, like Ukraine, there are serious problems with alcohol misuse. The article contains detailed information about the parlous state of services, which was gathered by the authors during an official visit to mental healthcare institutions 2 years ago. Sadly, the low salaries paid to psychiatrists (even by Moldovan, let alone international, standards) mean that barely any doctors train to enter our profession.

\section{Delivering psychiatric services in primary care: is this the right way to go for Ukraine?}

\section{Igor Martsenkovsky, ${ }^{1}$ Volodymyr Martyniuk ${ }^{2}$ and Dennis Ougrin ${ }^{3}$}

\begin{abstract}
${ }^{1}$ Head of the Department of Medical-Social Rehabilitation of Children and Adolescents with Mental and Behavioural Disorders, Ukrainian Institute of Social and Forensic Psychiatry and Drug Misuse, Kiev, Ukraine; ${ }^{2} \mathrm{Head}$ of the Department of Child Neurology and Medical-Social Rehabilitation of the P. L. Shupik National Medical Academy of Postgraduate Education, Kiev, Ukraine; ${ }^{3}$ Kraupl-Taylor Research Fellow, Department of Child and Adolescent Psychiatry, Institute of Psychiatry, King's College London, London, UK, email dennis.ougrin@iop.kcl.ac.uk
\end{abstract}

$\mathrm{U}_{\mathrm{d}}^{\mathrm{k}}$ kraine is a newly independent state with a population of about 48 million. It inherited its national health system from the USSR. The Soviet system was conceived as part of a massively expensive socialist planning economy that was generally delivering poor value for money. Some aspects of the Soviet health system were, however, undoubtedly sound and certain public health measures were superior to those in the West. For example, infant mortality, 
despite possible underreporting, was probably lower in the USSR than in many Western countries (Anderson \& Silver, 1986). The health system became increasingly corrupt and inefficient during the final years of the USSR's existence. Since independence, the health system has not been a state priority and has been chronically under-funded. In the past few years of rapid economic development in Ukraine, the share of the state budget allocated to the health system has remained static, leaving Ukraine in a disadvantaged state compared with other European countries (United Nations, 2007).

\section{The Ukrainian health system}

The basis of Ukrainian service provision is a system of highly specialised secondary care. There is also a network of general doctors (called district physicians and paediatricians) responsible for a given urban catchment area. Services are delivered by a network of acute hospitals and polyclinics that provide primary and secondary out-patient services. It is of interest that, in the UK, Lord Darzi, the Parliamentary Under-Secretary of State at the Department of Health, has recommended that there be greater access to secondary care in the community (Department of Health, 2007), a system not dissimilar to the polyclinics that have long been in operation in the USSR but which are now being dismantled in Ukraine.

Regional authorities fund the local health services and so the system is largely decentralised and relies on local budgets.

\section{Healthcare reforms and the delivery of mental health services in primary care}

The primary objective of healthcare reform in Ukraine, as in other post-Soviet countries (Saxena \& Maulik, 2003), is to develop a primary care system from existing resources, and so it has an opposite focus to the health reform currently proposed in the UK. One of the most important questions about the proposed strategy adopted by the Ukrainian Ministry of Health concerns the delivery of mental health services in the new primary care setting.

There are more than 5000 general practitioners in Ukraine, called family doctors. Their numbers increase every year. However, the role of these doctors in the treatment and prevention of mental disorders remains controversial. Three conceptually different views on this matter are currently being discussed.

\section{The ortho-psychiatric view}

The first approach the authors would call 'ortho-psychiatric'. A significant minority of senior psychiatrists and psychiatric academics seem irritated by the mere suggestion of the reforms going ahead and family doctors diagnosing and managing psychiatric disorders. Some psychiatrists argue that family doctors are not adequately trained to deliver high-quality psychiatric services and consider this to be a fundamentally dangerous public health situation. They fear a significant reduction in the funding of secondary mental health services. If any compromise is possible, they would probably agree with a possibility of family doctors diagnosing and managing mild depressive disorders and mild somatoform conditions (Lipelis, 2007).

An important factor supporting the ortho-psychiatric approach is the presence of an autonomous, populous and well-structured secondary psychiatric service in Ukraine. There are roughly 5000 psychiatrists and substance misuse specialists (who have separate training in Ukraine) and over 500 child psychiatrists. There is also a myriad of psychiatrists working for different governmental services.

The process of diagnosing, engaging and treating patients with psychiatric disorders is still governed by a stigmatising and over-controlling system of 'registration' and compulsory follow-up. Some local authorities try to isolate psychiatric patients even further, by demanding that psychiatrists be responsible for the general medical needs of their psychiatric patients. For instance, one of the major psychiatric hospitals in Kiev has a 'somatic' polyclinic delivering general practice services to psychiatric patients. This polyclinic was opened following an initiative by the Kiev city government.

\section{The official stance}

The second conceptual approach we would call 'formallegal'. This is the approach widely adopted by the authorities and is reflected in the current legislation. The authorities are trying to accommodate the general public's desire for a balance between the highest qualification of the doctors providing psychiatric care on the one hand, and de-stigmatising and de-institutionalising psychiatric care on the other.

Addressing this dilemma in legislation is not easy (Yudin, 2007). According to the 2000 legislation on psychiatric services (Supreme Rada of Ukraine, 2000), psychiatric services can be delivered only by psychiatrists at appropriate institutions. However, according to a separate government instruction (Cabinet of Ministers of Ukraine, 2000) and a Ministry of Health instruction (Ministry of Health of Ukraine, 2001), family doctors are supposed to be competent in diagnosing and managing urgent psychiatric conditions, 'masked' depressions, substance misuse disorders and so on. The instruction of the Ministry of Health has a lower status than the legislation and therefore cannot address the problems described.

There is a valid view among the Ukrainian population that general practitioners' care may be the least stigmatising and may improve access to psychiatric services. Many patients who would not accept a psychiatric diagnosis would agree to a psychological or neurological formulation. In fact, most Ukrainian psychiatric clinics are still officially called 'neuropsychiatric'. Nearly $30 \%$ of individuals with schizophrenia consult a neurologist in the first instance (Mikhailov et al, 2001), before being referred to a psychiatrist.

\section{The family doctors' view}

The third conceptual approach to this problem is reflected by the family doctors themselves (Serdiuk, 2006). At the moment, many family doctors feel unprepared for the diagnosis and management of psychiatric conditions and continue to refer most psychiatric patients to secondary care. Many family doctors do, though, appear to favour a broader role for primary care in the management of psychiatric conditions. But the main focus is seen as the prevention of mental 
illness, especially in high-risk groups. Family doctors, according to this approach, may focus on prevention, but also be able to make preliminary diagnoses of and manage common psychiatric conditions and maintain close links with secondary care for treatment-resistant and complex cases.

\section{How provision of mental health services might fit with the current work of family doctors}

Are Ukrainian family doctors prepared to face these challenges? Using standardised monitoring cards, researchers at the Department of Social Medicine, Health Governance and Management of Kharkiv Medical Academy of Postgraduate Studies, under the supervision of the first author (IM), carried out an analysis of the working time structure of family doctors in rural areas of Kharkiv region. They analysed 36 working weeks of the family doctors who worked in the 24 out-patient departments of that region. Of note, only $38 \%$ of the working time was spent delivering diagnostic and treatment services, the rest being classified as 'prevention'.

Surprisingly, each doctor delivered psychiatric services to only 1.2 patients a week on average, and each consultation lasted an average of 28.4 minutes. Only $1 \%$ of the working time was dedicated to delivering psychiatric services. Although the total number of patients to whom family doctors were delivering psychiatric services was low, each patient required a longer consultation on average than the medical patients. This analysis would suggest that an increase in the numbers of psychiatric patients seen may change the current working time schedules significantly and may be associated with significant opportunity cost.

\section{What is the way forward?}

There is a tension between the views of psychiatric professionals, family doctors, officials and the general public on the delivery of psychiatric services in primary care in Ukraine. This is a problem common to most post-Soviet countries and it deserves serious consideration. On the one hand, increasing the expertise of the primary care clinicians in the delivery of psychiatric services is urgently needed. On the other hand, it seems unwise to dismantle a well-developed, albeit inefficient, psychiatric secondary care system, certainly not before primary care professionals develop sufficient expertise and experience.

The modernisation of secondary care should be coordinated with the development of primary care. National legislation is one of the driving forces of reform and different legislative acts need to be urgently revised in order to be consistent with, yet responsive to, the views of both service users and the general public. This is a task that is currently only beginning to be addressed in Ukraine. Closer international cooperation may provide some assistance in addressing this issue. In particular, wider information exchange through conferences, training and publications may inform the reforms in Ukraine and other post-Soviet countries.

\section{Acknowledgements}

This work was supported by the Psychiatry Research Trust.

\section{References}

Anderson, B. \& Silver, B. (1986) Infant mortality in the Soviet Union: regional differences and measurement issues. Development Review, $12,705-737$

Cabinet of Ministers of Ukraine (2000) Postanova Kabinetu Ministriv Ukrayiny vid 20 chervnia 2000 roku N 989 pro komplekshi zakhody vprovadzhennia simeynoyi medytsyny $v$ systemu okhorony zdorovya. [Comprehensive plan of the development of family medicine in the health system, N989, 20 June 2000.] Official Journal of Ukraine, 25, 130. Available at http://uiph.kiev.ua/ua/..\%5Cua\%5Cextra\%5Crez 5.html (last accessed 18 March 2008).

Department of Health (2007) Our NHS Our Future: NHS Next Stage Review - Interim Report. Available at http://www.dh.gov.uk/en/ Publicationsandstatistics/Publications/PublicationsPolicyAndGuidance/ dh 079077 (last accessed 18 March 2008)

Lipelis, G. (2007) Obosnavannoye primeneniye antidepressantov v terapii depressivnykh rosstroystv. Natsionalnoye soveshchanije ekspertov. [Evidence-based use of antidepressants in the management of depression. National experts' meeting.] Neuronews, 5, 40. Available at http://neuro.health-ua.com/article/40.html (last accessed 18 March 2008).

Mikhailov, B., Serdyuk, O. \& Kanischev, A. (2001) Shliakhy rozvytku konsultatyvnoyi psykhiatriyi v Ukrayini [Ways of developing consultation psychiatry in Ukraine.] Ukrainian Psychoneurology Journal, 4, 62-63.

Ministry of Health of Ukraine (2001) Instruction of the Ministry of Health 'About approval of certain documents regarding family medicine', N7 23 February 2001. Available at http://www.kmu.gov.ua (last accessed 18 March 2008).

Saxena, S. \& Maulik, P. K. (2003) Mental health services in low- and middle-income countries: an overview. Services research and outcomes. Current Opinion in Psychiatry, 16, 437-442.

Serdiuk, O. (2006) Psykhiatrychna dopomoha $v$ praktytsi spetsialistiv zahalnoyi praktyky ta simeynoyi medytsyny. [Psychiatric services in the practice of general physicians and family doctors.] Neuronews, 1, $8-11$.

Supreme Rada of Ukraine (2000) Zakon Ukrayiny pro Psychiatrychnu Dopomohu. [Law of Ukraine on Psychiatric Aid.] Supreme Rada of Ukraine Journal, 19, 143-165. Available at http://zakon.nau.ua/eng/ doc/?uid=3020.133.0 (last accessed 18 March 2008).

United Nations (2007) World Population Prospects (2006 revision). Available at http://www.un.org/esa/population/publications/wpp2006/ WPP2006_Highlights_rev.pdf (last accessed 18 March 2008).

Yudin, B. (2007) Pravovyye aspekty okazaniya psikhiatricheskoy pomoshchi vrachami somaticheskogo profilia. [Legal aspects of delivering psychiatric services by general physicians.] Neuronews, 5, 21. Available at http://neuro.health-ua.com/article/21.html (last accessed 18 March 2008).

International Psychiatry is committed to the promotion of high-quality research and reporting from and about low- and middleincome countries, and cross-cultural and cross-national collaboration in the advancement of clinical science, education and advocacy in psychiatry and mental health. The original papers section of International Psychiatry is dedicated to the publication of high-quality original research and systematic reviews. Papers will be peer-reviewed quickly, for publication in the next available issue of the journal, although not all papers will be accepted for publication. Articles should be no more than 1500 words, with a maximum of two tables or figures and 12 key references. Wherever possible, our expert panel of assessors will help authors to improve their papers to maximise their impact when published. Please send your submissions to ip@rcpsych.ac.uk. 